\title{
Protein Energy Wasting in a Sample of Egyptian Children on Regular Hemodialysis: Relation to Anorexigenic Hormones
}

\author{
Ragia M. Said ${ }^{1}$, Maged A. El Wakeel ${ }^{2}$, Ghada M. El-Kassas ${ }^{2 *}$, Hend H. Mostafa ${ }^{2}$, Alyaa H. Kamhawy ${ }^{2}$, Essam M. Galal ${ }^{2}$, \\ Maysa S. Nassar ${ }^{2}$, Salwa Refat El-Zayat ${ }^{3}$, Nevein N. Fadl ${ }^{3}$ \\ ${ }^{1}$ Department of Pediatrics, Faculty of Medicine, Ain Shams University, Cairo, Egypt; ${ }^{2}$ Department of Child Health, National \\ Research Centre, Cairo, Egypt; ${ }^{3}$ Department of Medical Physiology, National Research Centre, Cairo, Egypt
}

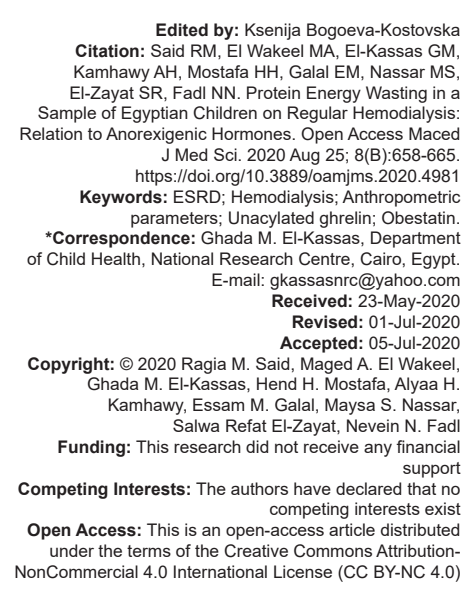

Introduction

Chronic kidney disease (CKD) in children is a serious public health problem [1]. The overall number of pediatric patients with end-stage renal disease (ESRD) needing renal replacement therapy has increased significantly [2].

Nutritional status is particularly important in children as it influences growth, sexual, and neurocognitive development. Its accurate and routine assessment is strongly recommended in pediatric patients undergoing regular hemodialysis (HD) [3].

Protein-energy wasting (PEW) and growth retardation are typical issues in pediatric CKD associated with lower quality of life and robustly predict morbidity and mortality [4], in particular, ESRD imposing maintenance dialysis treatment [5], [6], [7].

Malnutrition contends a pivotal role in the development of stunted growth, commonly observed in children with CKD. The pathophysiology of malnutrition and wasting in pediatric CKD is complex, multifaceted, and not yet fully established. Various factors are potentially elaborated, embracing; uremic toxins retention, metabolic acidosis, elevated circulating pro-inflammatory cytokines, insulin resistance, besides the occurrence of depression secondary to the disease per se [8], [9].

Negative energy balance is one of the virtually important interposed mechanisms of PEW, imposed by increasing energy expenditure and reduced food intake [10], [11]. That may be consequential to anorexia due to variable mechanisms, including nausea, early satiety due to delayed gastric emptying, altered food taste, and smell, in some patients, the need to drink plenty of fluid to keep up with high urine output. Perturbations in anorexigenic/orexigenic hormonal balance may be a pivotal key in the pathogenesis of PEW in children with CKD [5], [12].

Ghrelin and obestatin are appetite regulatory hormones, originated from the same ghrelin gene 
(GHRL), and produced by the stomach [13]. Their potential roles in uremic PEW have been investigated in adults [14], [15], [16] and, to a lesser extent, in pediatric CKD [17], [18], [19], with contradictory issues.

Ghrelin is a 28-amino acid peptide hormone secreted primarily by the oxyntic cells of the stomach. It is principally metabolized and excreted through the kidneys. Ghrelin is known as one of the most important appetite-regulating hormones. Two major circulating ghrelin forms detected; acyl ghrelin (AG), the active form, with orexigenic effect and the unacylated ghrelin (UAG), the main circulating ghrelin form, representing $>90 \%$, which appears to have the ability of increasing energy expenditure by declining food intake through the hypothalamus [20].

Obestatin (ghrelin-associated peptide) produced by the stomach from the same ghrelin gene, also recognized to have a homologous anorexigenic effect, fullness sensation, as well as slowing peristalsis [21].

To our knowledge, up till now, no studies have been done assessing the role of the hormones regulating energy homeostasis in Egyptian children with CKD, so in this study, we aimed to measure serum levels of UAG and obestatin in a group of Egyptian children with CKD on regular HD and to investigate their association with the anthropometric parameters in these hemodialyzed children.

\section{Patients and Methods}

This cross-sectional case-control study had been conducted on fifty children with an age range between 5 and 16 years, suffering from chronic renal failure, of variable durations on regular HD therapy, they have been recruited from the Department of Nephrology, Pediatric Hospital, Ain Shams University. Forty age- and sex-matched healthy children had been included as a control group. Exclusion criteria were treatment with growth hormone and/or the presence of neurologic disability or syndromes affecting per se food intake, patients with severe conditions such as generalized inflammation or end-stage malignant diseases.

Full history had been taken from the parents, including the original renal disease, previous interventions for renal problems, concomitant medications, child's previous growth and development, precise timing, and sequence of the physical milestones. Clinical examination and anthropometric indices have been evaluated. Height was measured by the Harpenden stadiometer in centimeters. Weight was recorded in kilograms using an electronic weight scale. Body mass index (BMI) had been calculated by weight in $\mathrm{kg} /(\text { height in meters) })^{2}$. Z scores of height for age, weight for age, and BMI were calculated using AnthroPlus Program for personal computers based on the WHO growth standards [22]. Waist circumference (at the smallest point between the rib cage and the iliac crest) has been measured in centimeters using a flexible inextensible tape, and then waist/height (WHR) had been calculated. Biceps, triceps, subscapular and suprailiac skinfold thicknesses were measured by Holtain skinfold calipers. The percentage of fat mass (FM \%) was calculated according to the Siri equation [23]. The parents of all participating children signed a written informed consent before taking part in the study, after explanation of the study's objectives

About $3 \mathrm{ml}$ of fasting 12 hours venous blood samples were withdrawn from all subjects, centrifuged at 3000 r.p.m. for $10 \mathrm{~min}$ and sera were separated then, stored at $-20^{\circ} \mathrm{C}$ untillaboratory analysis. Serum creatinine was determined also on Hitachi AutoAnalyzer, Hitachi 736 (Roche Diagnostics GmbH, D-68298 Mannheim, USA) using colorimetric techniques. Serum albumin was determined using the bromocresol green method (Orthoclinical Diagnostics Inc., Rochester, NY, USA). Serum levels of obestatin and UAG were measured using a commercial enzyme-linked immunosorbent assay (ELISA) kit, produced by Glory Science Co., Ltd. 2400 Veterans Blvd. Suite 16-101, Del Rio, TX 78840, USA. The detection range of the obestatin kit was $20 \mathrm{ng} / \mathrm{L}-$ $400 \mathrm{ng} / \mathrm{L}$, catalog number \#:17526. The detection range of the ghrelin kit was $3 \mathrm{pg} / \mathrm{ml}-200 \mathrm{pg} / \mathrm{ml}$ catalog number \#: 95622. The serum concentration of insulin was quantitatively determined by ELISA kit produced by (Chemux Bioscience, Inc, USA), a commercial kit of insulin was processed according to the manufacturer's instructions. The assay sensitivity was found to be $2.0 \mu \mathrm{lU} / \mathrm{ml}$. Fasting serum glucose, total cholesterol, and triglycerides (TG) were measured on BioSystems BTS-302 photometer by an enzymatic colorimetric method using the Bio-Diagnostic kit (Egypt) [24]. HDLcholesterol (HDL-C) was measured by the precipitation endpoint method, the supernatant was separated, and HDL-C was determined using the same method for total cholesterol described above. Serum LDL-cholesterol (LDL-C) levels were calculated using the Friedewald formula (LDL-C = Total cholesterol-HDL-C-[TG/5]) [25]. Insulin resistance was calculated by the homeostasis model assessment for insulin resistance (HOMA-IR) by the formula (fasting insulin $[\mathrm{mlU} / \mathrm{ml}] \times$ fasting glucose $[\mathrm{mg} / \mathrm{dl}] / 405)$. Considering insulin resistance if HOMA-IR index exceeding 3.16 [26].

\section{Statistical analysis}

Data were analyzed using IBM SPSS Statistics v. 22. Independent t-test was used for comparison between quantitative data of the two studied groups; normally distributed variables have been expressed as mean \pm SD. The correlation between two quantitative parameters in the same group was assessed by 
Pearson correlation analysis. Statistical significance was considered when $p<0.05$.

\section{Results}

The current study included 50 hemodialyzed children and 40 age- and sex-matched healthy Egyptian children as a control group, their mean age was (12.8 \pm 3.01 and $13.5 \pm 2.6$ years), respectively. According to primary renal disease, $12(24 \%)$ patients had post renal cause, while $38(76 \%)$ patients had intrinsic renal disease. Their anthropometric measurements as shown in Table 1 indicating statistically significant decrease in the hemodialyzed group than that of the control group (all $p<0.05$ ), except for waist-height ratio.

Table 1: Comparison between cases and controls as regards anthropometric measures

\begin{tabular}{|c|c|c|c|}
\hline Variables & $\begin{array}{l}\text { Hemodialyzed children } \\
(n=50) \text { Mean } \pm S D\end{array}$ & $\begin{array}{l}\text { Control } \\
(n=40) \text { Mean } \pm S D\end{array}$ & $p$-value \\
\hline Age (years) & $12.8 \pm 3.01$ & $13.5 \pm 2.6$ & 0.306 \\
\hline Wt-z score & $-3.00 \pm 1.72$ & $0.05 \pm 1.11$ & $<0.001^{\star *}$ \\
\hline Ht z-score & $-2.87 \pm 1.60$ & $1.38 \pm 0.42$ & $<0.001^{* *}$ \\
\hline BMI z-score & $-1.41 \pm 1.25$ & $1.38 \pm 0.42$ & $<0.001^{\star *}$ \\
\hline Waist circumference & $62.78 \pm 8.0$ & $79.8 \pm 11.10$ & $0.003^{\star *}$ \\
\hline Waist-height ratio (W/H) & $0.48 \pm 0.07$ & $0.45 \pm 0.04$ & 0.3 \\
\hline Biceps-SFT (mm) & $5.11 \pm 1.61$ & $8.42 \pm 2.45$ & $0.004^{\star *}$ \\
\hline Triceps-SFT(mm) & $7.05 \pm 2.20$ & $10.10 \pm 2.58$ & $0.01^{*}$ \\
\hline Subscapular-SFT(mm) & $6.38 \pm 2.50$ & $8.95 \pm 2.78$ & $0.02^{*}$ \\
\hline Suprailiac-SFT (mm) & $5.68 \pm 2.72$ & $8.89 \pm 2.95$ & $0.005^{\star *}$ \\
\hline
\end{tabular}

Biochemical features of the studied groups shown in Table 2 with a statistically significant increase of the levels of UAG, obestatin, insulin, glucose, HOMA-IR, and TG, while a significant decrease of HDL-C and albumin in the studied hemodialyzed children than that of the control group $(p<0.05)$.

Table 2: Comparison between cases and controls as regards biochemical features

\begin{tabular}{|c|c|c|c|}
\hline Variables & $\begin{array}{l}\text { Hemodialyzed children } \\
(n=50) \text { Mean } \pm S D\end{array}$ & $\begin{array}{l}\text { Control } \\
(n=40) \text { Mean } \pm S D\end{array}$ & $\mathrm{p}$-value \\
\hline Unacylated ghrelin (pg/ml) & $111.45 \pm 31.15$ & $87.59 \pm 28.47$ & $0.002^{* *}$ \\
\hline Obestatin (ng/L) & $223.73 \pm 88.72$ & $145.31 \pm 19.78$ & $<0.001^{* *}$ \\
\hline Insulin $(\mu \mathrm{IU} / \mathrm{ml})$ & $22.45 \pm 12.76$ & $9.46 \pm 12.56$ & $<0.001^{\star *}$ \\
\hline Glucose (mg/dl) & $112.99 \pm 31.84$ & $71.2 \pm 12.85$ & $<0.001^{* \star}$ \\
\hline HOMA-IR & $6.08 \pm 4.53$ & $1.73 \pm 2.39$ & $<0.001^{* \star}$ \\
\hline Total cholesterol $(\mathrm{mg} / \mathrm{dl})$ & $97.57 \pm 47.47$ & $95.00 \pm 11.87$ & 0.744 \\
\hline TG $(\mathrm{mg} / \mathrm{dl})$ & $162.4 \pm 74.54$ & $86.6 \pm 22.2$ & $<0.001^{* *}$ \\
\hline HDL-cholesterol (mg/dl) & $53.91 \pm 8.97$ & $71.00 \pm 22.2$ & $<0.001^{* \star}$ \\
\hline LDL-cholesterol (mg/dl) & $45.27 \pm 36.1$ & $38.27 \pm 7.51$ & 0.239 \\
\hline Albumin (g/dl) & $3.28 \pm 0.54$ & $4.89 \pm 0.9$ & $0.03^{*}$ \\
\hline
\end{tabular}
significant difference from controls.

There were inverse statistically significant correlations between UAG with Wt-z score (Figure 1), $\mathrm{Ht}$ z-score and FM \%, and also between obestatin with Wt-z score, BMI z-score (Figure 2), waist circumference, and waist-height ratio $(\mathrm{W} / \mathrm{H})$. A statistically significant negative correlation between UAG and albumin was detected. Both UAG and obestatin showed a statistically significant positive correlation with predialysis creatinine (Table 3).

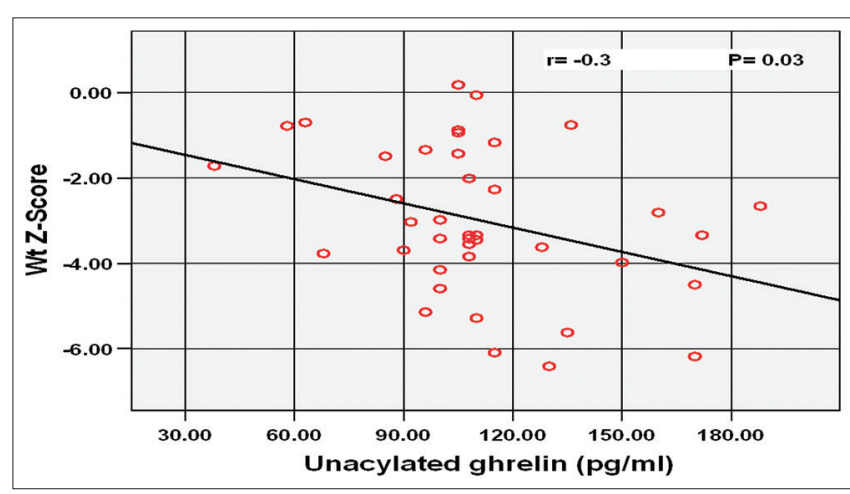

Figure 1: Correlation between unacylated ghrelin and Wt-z score in hemodialyzed group

\section{Discussion}

The current study assessed the relationship between anthropometric parameters and serum levels of UAG and obestatin in a group of Egyptian children with ESRD on regular HD to investigate the association between these anorexigenic hormones with growth retardation and wasting of these pediatric hemodialyzed patients.

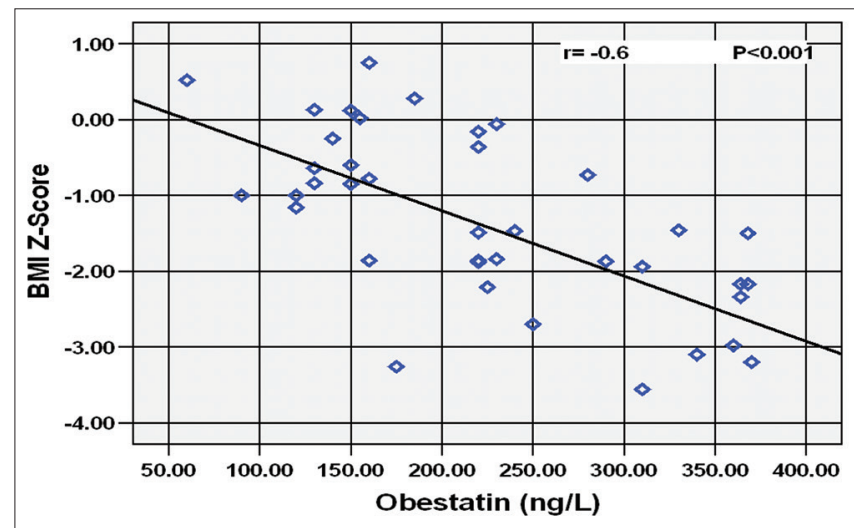

Figure 2: Correlation between obestatin and BMI z-score in hemodialyzed group

As regarding the anthropometric measurements, a statistically significant decline of all anthropometric indices was observed in hemodialyzed children when compared with their healthy pears,

Table 3: Correlations between serum unacylated ghrelin, obestatin, and other variables

\begin{tabular}{|c|c|c|c|c|}
\hline \multirow[t]{2}{*}{ Variables } & \multicolumn{2}{|c|}{ Unacylated ghrelin (pg/ml) } & \multicolumn{2}{|c|}{ Obestatin (ng/L) } \\
\hline & $r$ & $\mathrm{p}$ & $r$ & $\mathrm{p}$ \\
\hline Wt-z score & -0.343 & $0.03\left(^{*}\right)$ & -0.434 & $\left.0.005^{(*}\right)$ \\
\hline Ht z-score & -0.452 & $0.003\left({ }^{\star *}\right)$ & -0.140 & 0.389 \\
\hline BMI z-score & -0.008 & 0.959 & -0.612 & $0.000\left(^{* *}\right)$ \\
\hline Waist circumference & -0.053 & 0.746 & -0.328 & $\left.0.039^{*}\right)$ \\
\hline Waist-height ratio $(\mathrm{W} / \mathrm{H})$ & 0.025 & 0.878 & -0.456 & $\left.0.003^{(* *}\right)$ \\
\hline Fat mass (FM \%) & -0.511 & $0.002\left(^{*}\right)$ & -0.295 & 0.06 \\
\hline Creatinine & 0.402 & $0.01\left(^{*}\right)$ & 0.373 & $0.02\left(^{*}\right)$ \\
\hline HOMA-IR & -0.066 & 0.725 & -0.110 & 0.554 \\
\hline Total cholesterol $(\mathrm{mg} / \mathrm{dl})$ & 0.077 & 0.637 & -0.005 & 0.975 \\
\hline $\mathrm{TG}(\mathrm{mg} / \mathrm{dl})$ & -0.335 & $0.035\left(^{*}\right)$ & 0.002 & 0.989 \\
\hline HDL-cholesterol (mg/dl) & -0.003 & 0.986 & -0.023 & 0.890 \\
\hline LDL-cholesterol (mg/dl) & -0.180 & 0.267 & 0.037 & 0.820 \\
\hline Albumin (g/dl) & -0.462 & $0.03\left(^{*}\right)$ & -0.136 & 0.354 \\
\hline
\end{tabular}


except for waist-height ratio that showed an increase, the ratio might be influenced by a severe decline in the height parameter than waist circumference of the hemodialyzed group. Weight z-score was the most affected anthropometric parameter (37 patients = $74 \%$ with underweight and 13 patients $=26 \%$ with normal weight). Many studies came in agreement with our global finding of impaired anthropometrics but with some differences about the details due to different CKD series, and age groups with different development stages. In the same context of our findings, receiving dialysis treatment was associated with being underweight [27]; similarly, underweight was predominant in the hemodialyzed group [19], while percentages of overweight increased in CKD with renal transplant (maybe a drug effect due to corticosteroids administration, besides, appetite recovery after renal transplant therapy) [27]. In the contrast, the height was the most affected anthropometric parameter than weight in some studies [28], [29], [30].

In the present study, obestatin and UAG were statistically significantly higher in hemodialyzed children than control $(223.73 \pm 88.72$ vs. $145.31 \pm 19.78, p<0.001)$ and $(111.45 \pm 31.15$ vs. $87.59 \pm 28.47, p=0.002)$, respectively. On the same context, Monzani et al. [19] who measured ghrelin (acylated and unacylated) and obestatin in 110 pediatric CKD (42 on conservative treatment, 20 on $\mathrm{HD}$, and 48 transplantation recipients) and 43 controls, recording elevated UAG and obestatin concentrations in uremic children, notably in hemodialyzed than nondialyzed CKD patients and controls. Furthermore, increased total ghrelin with alternated AG/total ghrelin ratio (denoting elevation of UAG) in patients with ESRD undergoing dialysis was previously reported in many studies [31], [32], [33], [34], [35].

Both UAG and obestatin hormones showed a statistically significant positive correlation with predialysis levels of serum creatinine in the present study, confirming preceding findings have been reported by many researchers, with a suggested trend to increase of these anorexigenic hormones with the progression of renal impairment [19], [31], [36], [37].

Some researchers suggested that elevated levels of anorexigenic hormones such as obestatin and UAG observed in children with CKD on HD could be part of a defensive strategy to prevent the accumulation of toxic metabolites, which are normally cleared through the kidneys [19], prolonged half-life due to reduced renal clearance of these hormones under uremic conditions [38]. In addition, alterations in the activity of the enzymes involved in ghrelin deacylation, as uremic dyslipidemia may impair their function [39]. It may be ascribed to the inflammatory and substandard nutritional status of uremic patients [35].

Some studies were controversial, by their revealed normal or even subnormal serum levels of ghrelin in CKD patients on dialysis [14], [15], a possible clarification for this controvert might be that only UAG levels were elevated in the CKD patients. For instance, Gupta et al. [37] measured serum levels of AG and UAG levels in $51 \mathrm{CKD}$ and 15 hemodialyzed patients, then demonstrated increased UAG levels with declining estimated glomerular filtration rate, while serum levels of AG kept unchanged.

On the other side, the study of Mafra et al. [40] has revealed low levels of obestatin and high levels of des-AG in hemodialyzed patients. However, lean patients had elevated levels of obestatin and des-AG. Despite, obscured by the unchanged obestatin levels after a meal in patients on maintenance $\mathrm{HD}$, the relationship between sense of fullness and obestatin detected by Beberashvili et al. [41] might stipulate obestatin to behave as an anorexigenic. Up till now, there is controversy about the level of obestatin and its potential role, as an anorexigenic hormone, in the regulation of appetite and long-term food intake besides, its influence on the nutritional status and anthropometry in the hemodialyzed population [21], [40], [41], [42].

Despite, the variability of obestatin and UAG levels in CKD [9], [19], [34], [43], it has been postulated that disparity of these appetite-regulating hormones might assist in the defective appetite and PEW in uremic patients [44], [45], by an anorexigenic effect [33], as a compensatory response reflecting imbalanced energy status [46].

The current study revealed statistically significant negative correlations between UAG with Wt-z score, $\mathrm{Ht}$ Z-score, and FM \%, also between obestatin with Wt-Z score, BMI z-score, waist circumference, and waist-height ratio $(\mathrm{W} / \mathrm{H})$, so both anorexigenic hormones are found to be inversely related to the anthropometric indices, besides, the statistically significant inverse relationship between UAG and albumin in these uremic pediatric patients.

To some extent, the findings of previous researches came in accordance with our conclusion about the negative correlation between the ghrelin system and the anthropometric parameters in CKD patients [35], [47], and healthy children [48]. Similarly, the inverse correlations between obestatin, BMI $(r=-0.40, p=0.007)$, and waist circumference ( $r=-0.38, p=0.024)$ reported by Mafra et al. [40].

Furthermore, Monzani et al. [19] gave accentual evidence concerning the negative correlation between obestatin, UAG, and the anthropometric parameters (negative association between UAG with weight-SDS and BMI-SDS, also between obestatin with weight-SDS). These results help them to consider the hormones of UAG and to less extent, obestatin as promising inverse biomarkers of nutritional state in pediatric CKD patients, while on the contrast of our findings, they did not detect any relations between these two hormones and waist circumference, waistheight ratio, or serum albumin.

In another respect, the reported results of the studies done by Eftekhari et al. [18] and Monzani et al. [19] 
had confirmed our findings concerning the negative correlation between UAG and FM \%. They suspected UAG to be considered as a promising biomarker of muscle-wasting, known to be associated with deleterious long-term consequences in uremic subjects, even in conditions with normal BMI records [49].

In the present study, hypoalbuminemia (serum albumin $<3.5 \mathrm{mg} / \mathrm{dl}$ ) have been detected in CKD patients on HD. Serum albumin was considered as the most common nutritional marker in HD patients, strongly predicting mortality [50]. However, this was criticized by Stenvinkel et al. [51] due to its close link to other nonnutritional factors, mostly infection and inflammation [52].

There are strong existed data regarding dyslipidemia as a common finding in CKD patients, particularly those on maintenance HD, and its contribution to the risk of the high prevalence of cardiovascular disorders in these patients [53], [54].

Principally, dyslipidemia of CKD incorporated increased TG and decreased HDL-C levels [55], [56], this came in agreement with our findings of statistically significant increase of TG levels while a significant decrease of HDL-cholesterol in the studied hemodialyzed children than that of the control group $(p<0.01)$, with a non-significant increase of total cholesterol and LDL-C in the hemodialyzed group. Furthermore, previous studies reported similar findings [57], [58].

In the current study, no correlations have been detected between measured obestatin or UAG hormones and any of the lipid profile parameters, except for, the statistically significant negative correlation found between UAG and TG in the hemodialyzed group $(r=-0.335, p=0.035)$, otherwise, Monzani et al. [19] reported a statistically significant positive correlation between obestatin and TG $(r=0.195, p=0.02)$.

On the other hand, no correlations between ghrelin and lipid profile have been detected by some researchers [35], [47], [59]. Otherwise, some experimental studies supposed the ability of obestatin to reduce serum lipids through reduction of food intake and intestinal absorption of TG, besides stimulating leptin secretion and fatty acid uptake [60], [61], [62].

In the current study, HOMA-IR was statistically elevated in hemodialyzed patients with a nonsignificant negative correlation with obestatin and UAG. Moreover, insulin resistance was found to be a common finding in patients on maintenance $\mathrm{HD}$ even without diabetes [41], [63], Barazzoni et al. [64], [65] reported a strong negative association between UAG and HOMA-IR in their studies. In addition, Cappellari et al. [66] suggested an improvement of insulin activity due to overexpression of UAG in obesity-induced insulin resistance through reducing reactive oxygen species and increasing autophagy, with concomitant improvement of tissue inflammation.

Despite, the strong positive association between UAG and obestatin detected by Monzani et al. [19] and previously by Mafra et al. [40] suggesting clear association of the two hormones with common posttranslation regulation and a strong appetite management mechanism. On the contrast, this strong association could not be validated by our results due to the positive correlation between the two hormones was statistically non-significant. Ongoing the relationship between UAG and obestatin and their effect on the nutritional status and growth of CKD patients, especially those on maintenance HD still under debate and need more research.

\section{Conclusion}

The present study detected elevated serum levels of UAG and obestatin in hemodialyzed children compared to controls. Both hormones were negatively related to the anthropometric parameters, suggesting their link to the nutritional and growth impairment of these growing patients.

Further studies are needed to detect the role of the appetite regulators in CKD patients and their link to nutritional and growth impairment. This may help to provide reliable innovatory biomarkers for the diagnostic and therapeutic presumption of nutritional and growth defects in pediatric patients with CKD.

We recommend regular assessment of anthropometric and biochemical nutritional parameters in pediatric CKD, especially those on HD with regular follow-up by specialized dietitians.

\section{Acknowledgment}

The authors want to give thanks to all participants in the study (children and their families, lab, and clinic staff members) for their assistance and efforts.

\section{References}

1. Sanyaolu A, Okorie C, Annan R, Turkey H, Akhtar N, Gray F, et al Epidemiology and management of chronic renal failure: A global public health problem. Biostat Epidemiol Int J 2018;1(1):11-6. https://doi.org/10.30881/beij.00005

2. El-Ballat MA, El-Sayed MA, Emam HK. Epidemiology of end stage renal disease patients on regular hemodialysis in El-Beheira governorate, Egypt. Egypt $J$ Hosp Med 2019;76(3):3618-25

3. Lotfy HM, Sabry SM, Ghobrial EE, Abed SA. The effect of regular 
hemodialysis on the nutritional status of children with end-stage renal disease. Saudi J Kidney Dis Transpl 2015;26(2):263. https://doi.org/10.4103/1319-2442.152416

\section{PMid:25758873}

4. Foucan L, Merault H, Velayoudom-Cephise FL, Larifla L, Alecu C, Ducros J. Impact of protein energy wasting status on survival among Afro-Caribbean hemodialysis patients: A 3-year prospective study. Springerplus 2015;4(1):452. https://doi. org/10.1186/s40064-015-1257-3

PMid:26322258

5. Mak RH, Cheung WW, Zhan JY, Shen Q, Foster BJ. Cachexia and protein-energy wasting in children with chronic kidney disease. Pediatr Nephrol 2012;27(2):173-81. https://doi. org/10.1007/s00467-011-1765-5

PMid:21298504

6. Obi Y, Qader H, Kovesdy CP, Kalantar-Zadeh K. Latest consensus and update on protein energy-wasting in chronic kidney disease. Curr Opin Clin Nutr Metab Care 2015;18(3):254. https://doi.org/10.1097/mco.0000000000000171

PMid:25807354

7. Rezeq HA, Khdair LN, Hamdan ZI, Sweileh WM. Prevalence of malnutrition in hemodialysis patients: A single-center study in Palestine. Saudi J Kidney Dis Transpl 2018;29(2):332-40. https://doi.org/10.4103/1319-2442.229264

PMid:29657201

8. El Wakeel MA, El-Kassas GM, Hashem SA, Abouelnaga MW, Elzaree FA, Hassan M, et al. Potential role of oxidative stress in childhood obesity and its relation to inflammation. Biosci Res 2018;15(4):3791-9.

9. Wang Z, Oliveira EA, Mak RH. Unacylated ghrelin and obestatin in pediatric CKD: Are they important in protein energy wasting? Pediatr Nephrol 2018;33(5):741-3. https://doi.org/10.1007/ s00467-018-3891-9

PMid:29453692

10. Carrero JJ, Stenvinkel P, Cuppari L, Ikizler TA, KalantarZadeh $\mathrm{K}$, Kaysen $\mathrm{G}$, et al. Etiology of the protein-energy wasting syndrome in chronic kidney disease: A consensus statement from the international society of renal nutrition and metabolism (ISRNM). J Ren Nutr 2013;23(2):77-90. https://doi. org/10.1053/j.jn.2013.01.001

PMid:23428357

11. Zoccali C, Mallamaci F. Obestatin, a ghrelin-cognate protein, and clinical outcomes in hemodialysis patients. Am J Nephrol 2018;47(4):251-3. https://doi.org/10.1159/000488287 PMid:29694953

12. Bek SG, Batman A, Eraldemir C, Eren N, Bakirdogen S, Dervişoğlu E. Serum ghrelin levels: Is there any association with malnutrition and depres-sion in peritoneal dialysis patients? Hippokratia 2018;22(1):43-8.

PMid:31213757

13. Gil-Campos M, Aguilera CM, Canete R, Gil A. Ghrelin: A hormone regulating food intake and energy homeostasis. $\mathrm{Br} \mathrm{J}$ Nutr 2006;96(2):201-26. https://doi.org/10.1079/bjn20061787 PMid: 16923214

14. Pérez-Fontán M, Cordido F, Rodríguez-Carmona A, Peteiro J, García-Naveiro R, García-Buela J. Plasma ghrelin levels in patients undergoing haemodialysis and peritoneal dialysis. Nephrol Dial Transpl 2004;19(8):2095-100. https://doi. org/10.1093/ndt/gfh313

PMid:15187192

15. Iglesias P, Díez JJ, Fernández-Reyes MJ, Codoceo R, Alvarez-Fidalgo $\mathrm{P}$, Bajo MA, et al. Serum ghrelin concentrations in patients with chronic renal failure undergoing dialysis. Clin Endocrinol 2006;64(1):68-73. https://doi. org/10.1111/j.1365-2265.2005.02418.x

\section{PMid:16402931}

16. Sekar M, Elumalai R, Basappa MK, Lakkakula BV, Periasamy S. Effect of chronic kidney disease on circulating ghrelin concentrations. Ann RSCB 2015;19(2):41-6.

17. Abdelhamid ER, Kamhawy $A H$, Ahmed $H H$, Shady MM, Fathy A, Fahmy RF. Association of cord blood des-acyl ghrelin with Apgar score and anthropometric measures in relation to its maternal one. Biomed Pharmacol J 2019;12(3):1147-54. https:// doi.org/10.13005/bpj/1743

18. Eftekhari $\mathrm{MH}$, Ranjbar-Zahedani $\mathrm{M}$, Basiratnia $\mathrm{M}$ Rezaianzadeh A, Faghih S. Comparison of appetite-regulating hormones and body composition in pediatric patients in predialysis stage of chronic kidney disease and healthy control group. Iran J Med Sci 2015;40(1):27-33.

PMid:25649956

19. Monzani A, Perrone M, Prodam F, Moia S, Genoni G, Testa S, et al. Unacylated ghrelin and obestatin: Promising biomarkers of protein energy wasting in children with chronic kidney disease. Pediatr Nephrol 2018;33(4):661-72. https://doi.org/10.1007/ s00467-017-3840-z

PMid:29150712

20. Müller TD, Nogueiras R, Andermann ML, Andrews ZB, Anker SD, Argente J, et al. Ghrelin. Mol Metab 2015;4(6):437-60. PMid:26042199

21. Katkov A, Sinuani I, Azar A, Shapiro G, Efrati S, Beberashvili I. Age modifies the association between serum obestatin, appetite and nutritional status in maintenance hemodialysis patients. Eur J Clin Nutr 2018;72(7):1007-18. https://doi.org/10.1038/ s41430-018-0087-0

PMid:29362457

22. World Health Organization. WHO AnthroPlus for Personal Computers Manual: Software for Assessing Growth of the World's Children and Adolescents. Geneva: World Health Organization; 2009. Available from: http://www.who.int/ growthref/tools/en. [Last accessed on 2019 October 10].

23. Siri WE. Body composition from fluid spaces and density: Analysis of methods. Nutrition 1961 1993;9(5):223-44. PMid:8286893

24. Narasimha Rai K, Kumari NS, Damodara Gowda KM, Swathi KR. The evaluation of micronutrients and oxidative stress and their relationship with the lipid profile in healthy adults. $J$ Clin Diagn Res 2013;7(7):1314-8. https://doi.org/10.7860/ jcdr/2013/6127.3124 PMid:23998054

25. Friedewald WT, Levy RI, Fredrickson DS. Estimation of the concentration of low-density lipoprotein cholesterol in plasma, without use of the preparative ultracentrifuge. Clin Chem 1972;18(6):499-502. https://doi.org/10.1093/clinchem/18.6.499 PMid:4337382

26. Matthews DR, Hosker JP, Rudenski AS, Naylor BA, Treacher DF, Turner RC. Homeostasis model assessment: Insulin resistance and $\beta$-cell function from fasting plasma glucose and insulin concentrations in man. Diabetologia 1985;28(7):412-9. https:// doi.org/10.1007/bf00280883

PMid:3899825

27. Bonthuis M, Van Stralen KJ, Verrina E, Groothoff JW, Melgar AA Edefonti $A$, et al. Underweight, overweight and obesity in paediatric dialysis and renal transplant patients. Nephrol Dial Transplant 2013;28(Suppl 4):iv195-204. https://doi.org/10.1093/ ndt/gft259

PMid:23975752

28. Zaki ME, Hassan MM, Bazaraa HM, Ahmed HF. Nutritional status in children with chronic renal failure on hemodialysis. Maced J Med Sci 2012;5(3):296-301.

29. Rodig NM, McDermott KC, Schneider MF, Hotchkiss HM, 
Yadin O, Seikaly MG, et al. Growth in children with chronic kidney disease: A report from the chronic kidney disease in children study. Pediatr Nephrol 2014;29(10):1987-95. https:// doi.org/10.1007/s00467-014-2812-9

PMid:24728472

30. Rees L. Growth hormone therapy in children with CKD after more than two decades of practice. Pediatr Nephrol 2016;31(9):142135. https://doi.org/10.1007/s00467-015-3179-2 PMid:26369925

31. Arbeiter AK, Büscher R, Petersenn S, Hauffa BP, Mann K, Hoyer PF. Ghrelin and other appetite-regulating hormones in paediatric patients with chronic renal failure during dialysis and following kidney transplantation. Nephrol Dial Transplant 2009;24(2):643-6. https://doi.org/10.1093/ndt/gfn529

PMid:18809976

32. Naufel MF, Bordon M, de Aquino TM, Ribeiro EB, de Abreu Carvalhaes JT. Plasma levels of acylated and total ghrelin in pediatric patients with chronic kidney disease. Pediatr Nephrol 2010;25(12):2477-82. https://doi.org/10.1007/ s00467-010-1628-5

PMid:20734087

33. Büscher AK, Büscher R, Hauffa BP, Hoyer PF. Alterations in appetite-regulating hormones influence protein energy wasting in pediatric patients with chronic kidney disease. Pediatr Nephrol 2010;25(11):2295-301. https://doi.org/10.1007/ s00467-010-1588-9

PMid:20607302

34. Canpolat N, Sever L, Agbas A, Tasdemir M, Oruc C Ekmekci OB, et al. Leptin and ghrelin in chronic kidney disease: Their associations with protein-energy wasting. Pediatr Nephrol 2018;33(11):2113-22. https://doi.org/10.1007/ s00467-018-4002-7

PMid:29980850

35. El-Khashab SO, Behiry ME. Adiponectin and ghrelin: Nutritional regulatory role in chronic kidney disease patients. Egypt $\mathrm{J}$ Intern Med 2019;31(1):99. https://doi.org/10.4103/ejim.ejim_78_18

36. Yoshimoto A, Mori K, Sugawara A, Mukoyama M, Yahata K, Suganami $\mathrm{T}$, et al. Plasma ghrelin and desacyl ghrelin concentrations in renal failure. J Am Soc Nephrol 2002;13(11):2748-52. asn.0000032420.12455.74 PMid: 12397045

37. Gupta RK, Kuppusamy T, Patrie JT, Gaylinn B, Liu J, Thorner MO, et al. Association of plasma des-acyl ghrelin levels with CKD. Clin J Am Soc Nephrol 2013;8(7):1098-105. https:// doi.org/10.2215/cjn.09170912 PMid:23744005

38. Gutierrez JA, Solenberg PJ, Perkins DR, Willency JA, Knierman MD, Jin Z, et al. Ghrelin octanoylation mediated by an orphanlipidtransferase.ProcNatIAcadSci200829;105(17):63205. https://doi.org/10.1073/pnas.0800708105 PMid: 18443287

39. De Vriese C, Hacquebard M, Gregoire F, Carpentier $Y$, Delporte C. Ghrelin interacts with human plasma lipoproteins. Endocrinology 2007;148(5):2355-62. https://doi.org/10.1210/ en.2006-1281

PMid: 17289852

40. Mafra D, Guebre-Egziabher F, Cleaud C, Arkouche W, Mialon A, Drai J, et al. Obestatin and ghrelin interplay in hemodialysis patients. Nutrition 2010;26(11-12):1100-4. https:// doi.org/10.1016/j.nut.2009.09.003 PMid:20018486

41. Beberashvili I, Ptashkin E, Azar A, Hamad RA, Koren S, Stav K, et al. Obestatin levels in response to a meal and association with subsequent appetite sensations in maintenance hemodialysis patients. Clin Nutr 2020;2020:30063. https://doi.org/10.1016/j. clnu.2020.02.015

42. Depoortere I, Thijs T, Moechars D, De Smet B, Ver Donck L, Peeters TL. Effect of peripheral obestatin on food intake and gastric emptying in ghrelin-knockout mice. $\mathrm{Br} \mathrm{J}$ Pharmacol 2008;153(7):1550-7. https://doi.org/10.1038/sj.bjp.0707683 PMid: 18204478

43. Rees L. Protein energy wasting; what is it and what can we do to prevent it? Pediatr Nephrol 2019;1-8. https://doi.org/10.1007/ s00467-019-04424-2

PMid:31834488

44. Asakawa A, Inui A, Fujimiya M, Sakamaki $R$, Shinfuku $N$, Ueta $\mathrm{Y}$, et al. Stomach regulates energy balance via acylated ghrelin and desacyl ghrelin. Gut 2005;54(1):18-24. https://doi. org/10.1136/gut.2004.038737

PMid:15591499

45. Muscaritoli M, Molfino A, Chiappini MG, Laviano A, Ammann T, Spinsanti $\mathrm{P}$, et al. Anorexia in hemodialysis patients: The possible role of des-acyl ghrelin. Am J Nephrol 2007;27(4):3605. https://doi.org/10.1159/000103798 PMid: 17556836

46. Akamizu T, Kangawa K. Therapeutic applications of ghrelin to cachexia utilizing its appetite-stimulating effect. Peptides 2011;32(11):2295-300. https://doi.org/10.1016/j. peptides.2011.05.018 PMid:21635929

47. Ayala ER, Pecoits-Filho R, Heimbürger $O$, Lindholm $B$, Nordfors $L$, Stenvinkel P. Associations between plasma ghrelin levels and body composition in end-stage renal disease: A longitudinal study. Nephrol Dial Transplant 2004;19(2):421-6. https://doi.org/10.1093/ndt/gfg559

PMid:14736968

48. Prodam F, Monzani A, Ricotti R, Marolda A, Bellone S, Aimaretti G, et al. Systematic review of ghrelin response to food intake in pediatric age, from neonates to adolescents. J Clin Endocrinol Metab 2014;99(5):1556-68. https://doi.org/10.1210/ jc.2013-4010

PMid:24601727

49. Johansen $\mathrm{KL}$, Lee C. Body composition in chronic kidney disease. Curr Opin Nephrol Hypertens 2015;24(3):268. PMid:25887900

50. Alves FC, Sun J, Qureshi AR, Dai L, Snaedal S, Barany P, et al. The higher mortality associated with low serum albumin is dependent on systemic inflammation in end-stage kidney disease. PLoS One 2018;13(1):e0190410. https://doi. org/10.1371/journal.pone. 0190410

PMid:29298330

51. Stenvinkel $P$, Barany $P$, Chung $\mathrm{SH}$, Lindholm $B$, Heimbürger $O$. A comparative analysis of nutritional parameters as predictors of outcome in male and female ESRD patients. Nephrol Dial Transpl 2002;17(7):1266-74. https://doi.org/10.1093/ ndt/17.7.1266

PMid:12105251

52. Soeters PB, Wolfe RR, Shenkin A. Hypoalbuminemia: Pathogenesis and clinical significance. J Parenter Enteral Nutr 2019;43:181-93. https://doi.org/10.1002/jpen.1451 PMid:30288759

53. Qunibi WY. Dyslipidemia in dialysis patients. In: Seminars in Dialysis. Vol. 28. New York: Wiley Online Library; 2015. p. 34553. https://doi.org/10.1111/sdi.12375

54. Gluba-Brzozka A, Franczyk B, Rysz J. Cholesterol disturbances and the role of proper nutrition in CKD patients. Nutrients 2019;11(11):2820. https://doi.org/10.3390/nu11112820 PMid:31752189 
55. Ragab M, Ragab A. Assessment of lipid profile in Egyptian children with chronic kidney diseases on conservative therapy and those under regular hemodialysis. J Med Sci 2007;7(5):825-9.

56. Tannock L. Dyslipidemia in Chronic Kidney Disease. In: Endotext. San Francisco, CA: MDText Com, Inc.; 2018.

57. Ziegelmeier $M$, Bachmann A, Seeger J, Lossner $U$, Kratzsch J, Blüher $\mathrm{M}$, et al. Adipokines influencing metabolic and cardiovascular disease are differentially regulated in maintenance hemodialysis. Metabolism 2008;57(10):1414-21. https://doi.org/10.1016/j.metabol.2008.05.011

PMid:18803947

58. Shouman MG, Ibrahim HY, Bazaraa H, Salama EE, El Malt HA. Adipocytokines in pediatric hemodialysis patients. Res $\mathrm{J}$ Med Med Sci 2009;4:533-7?

59. Elsayed NM, Hamed ST, El-Khatib MM, El-Shehaby AM. The relation between dual energy $\mathrm{x}$-ray absorptiometry measurement of body fat composition and plasma ghrelin in patients with endstage renal disease. Saudi Med J 2009;30(1):109-15. PMid:19139783

60. Nagaraj S, Peddha MS, Manjappara UV. Fragments of obestatin as modulators of feed intake, circulating lipids, and stored fat. Biochem Biophys Res Commun 2008;366(3):731-7. https://doi. org/10.1016/j.bbrc.2007.12.036

61. Agnew A, Calderwood D, Chevallier OP, Greer B, Grieve DJ, Green BD. Chronic treatment with a stable obestatin analog significantly alters plasma triglyceride levels but fails to influence food intake; fluid intake; body weight; or body composition in rats. Peptides 2011;32(4):755-62. https://doi.org/10.1016/j. peptides.2010.12.005

PMid:21167891

62. Abulfadle KA, Saied AA. Role of obestatin in improvement of obesity-induced metabolic and kidney function changes in exercised rats. Am J Biomed Sci 2019;11(2):74-89. https://doi. org/10.5099/aj190200074

63. Hung AM, Ikizler TA. Factors determining insulin resistance in chronic hemodialysis patients. In: Hemodialysis. Vol. 171. Basel, Switzerland: Karger Publishers; 2011. p. 127-34. https:// doi.org/10.1159/000327177

64. Barazzoni R, Zanetti M, Ferreira C, Vinci P, Pirulli A, Mucci M, et al. Relationships between desacylated and acylated ghrelin and insulin sensitivity in the metabolic syndrome. J Clin Endocrinol Metab 2007;92(10):3935-40. https://doi.org/10.1210/ jc.2006-2527

PMid: 17652221

65. Barazzoni R, Cappellari GG, Semolic AN, lus M, Mamolo L, Dore $F$, et al. Plasma total and unacylated ghrelin predict 5-year changes in insulin resistance. Clin Nutr 2016;35(5):1168-73. https://doi.org/10.1016/j.clnu.2015.10.002

PMid:26508327

66. Cappellari GG, Zanetti M, Semolic A, Vinci P, Ruozi G, Falcione $A$, et al. Unacylated ghrelin reduces skeletal muscle reactive oxygen species generation and inflammation and prevents high-fat diet-induced hyperglycemia and whole-body insulin resistance in rodents. Diabetes 2016;65(4):874-86. https://doi.org/10.2337/db15-1019

PMid:26822085 